Article

\title{
Production of the Hydroxyl Radical and Removal of Formaldehyde by Calcined Green Tuff Powder and Tile
}

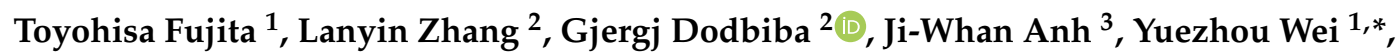 \\ Hiromi Kurokawa ${ }^{4}$, Hirofumi Matsui ${ }^{4}$, Shigeki Yamamoto ${ }^{5}$ and Hiroshi Kawaguchi ${ }^{5}$ \\ 1 College of Resources, Environment and Materials, Guangxi University, 100 Daxue Road, \\ Nanning 530004, China; fujitatoyohisa@gxu.edu.cn \\ 2 Graduate School of Engineering, the University of Tokyo 7-3-1 Hongo, Bunkyo-ku, Tokyo 113-8656, Japan; \\ zhanglanyin.zju@gmail.com (L.Z.); dodbiba@sys.t.u-tokyo.ac.jp (G.D.) \\ 3 Korea Institute of Geoscience and Mineral Resources (KIGAM), 92 Gwahang-no, Yuseong-gu, \\ Daejeon 305-350, Korea; ahnjw@kigam.re.kr \\ 4 Doctoral Programs in Medical Sciences, The University of Tsukuba, Tsukuba City, Ibaraki 305-8575, Japan; \\ hkurokawa.tt@md.tsukuba.ac.jp (H.K.); hmatsui@md.tsukuba.ac.jp (H.M.) \\ 5 Towada Green-tuff AgroScience Co., Ltd. Meguro-ku, Tokyo 152-0011, Japan; \\ yamamoto@toeidenka.co.jp (S.Y.); hiroshikwgc@gmail.com (H.K.) \\ * Correspondence: yzwei@gxu.edu.cn
}

Received: 10 May 2019; Accepted: 18 June 2019; Published: 19 June 2019 updates

\begin{abstract}
Waste green tuff powder produced by cutting Towada stone has been utilized to eliminate formaldehyde related to greenhouse gases. The green tuff contains $\mathrm{TiO}_{2}$ on zeolite as observed by scanning electron microscope (SEM)t. The green tuff is a natural catalyst that can produce hydrogen peroxide with moisture and oxygen with light. The optimum temperature for calcination of the green tuff powder has been investigated in order to produce hydroxyl radicals from the decomposition of hydrogen peroxide using ultraviolet light (UV) and no light. The green tuff calcined at $800{ }^{\circ} \mathrm{C}$ showed a high decomposition rate of hydrogen peroxide with no UV light under high alkaline conditions when measured by using ESR. With UV light, the optimum temperature for calcination of green tuff powder in order to reduce the hydroxyl radical was also $800^{\circ} \mathrm{C}$. Next, the powder calcined at $800{ }^{\circ} \mathrm{C}$ was used to produce the tile by compression and heating, and then the formaldehyde adsorption rate was measured. The green tuff powder calcined at $800{ }^{\circ} \mathrm{C}$ showed a high adsorption rate, similar to that of the activated carbon. The tiles formed at $40 \mathrm{MPa}$ and heated at $1100{ }^{\circ} \mathrm{C}$ were the strongest and also showed adsorption with respect to formaldehyde. The adsorbed formaldehyde on the green tuff tile and powder was possibility decomposed by the hydroxyl radical produced by photocatalysis.
\end{abstract}

Keywords: green tuff; towada stone; calcination; recycle; tile; hydrogen peroxide; radical; ESR; adsorption; formaldehyde; UV; photocatalysis

\section{Introduction}

For sustainable development, it is necessary to reduce greenhouse gases, not only $\mathrm{CO}_{2}$ but also other related gases and to recycle waste materials. In this report, by utilizing rock (green tuff) cutting waste powders, the possibility of reducing formaldehyde [1,2], which is a volatile organic compound recognized by WHO, was investigated. Green tuff is a sedimentary rock formed in rivers and lakes from 20 million to 15 million years ago and is distributed widely along the coast of the Sea of Japan in the Japanese Archipelago [3]. Nowadays, Hinai Green tuff, a beautiful greenish color block (Towada Stone) found in Akita prefecture, Japan, is utilized in building walls and floors, and so on [4]. However, 
when the tuff stone is quarried and ground, about $60 \%$ of all quarried stone becomes waste powders and about $4000 \mathrm{t}$ of powder per year are discharged and wasted. It is important to utilize a large amount of produced green tuff powder. Several applications have been suggested to use cutting powder of green tuff, for example, utilization in food processing [5], activation of microorganisms [6], precipitation regents for wastewater treatment [7], and adsorption of chemical substances [8]. Sugai et al. produced several boards of green tuff aggregate (1-3 $\mathrm{mm}$ and less than $1 \mathrm{~mm}$ in size) using a mixture with $40 \mathrm{wt} \%$ of white Portland cement at $20^{\circ} \mathrm{C}$ for 10 days. They measured the adsorption capacity of toluene and formaldehyde in the air using these boards and reported that the adsorption was similar to the board used in diatomaceous earth [8]. LIXIL Co. produced the "ECOCARAT" tile to adsorb the toluene and acetaldehyde [9]. Both articles explained that the reason for volatile chemical substance removal in the air was adsorption onto porous materials. However, the adsorption amount was limited. On the other hand, if the chemical substances can be decomposed by a photocatalyst, it is more effective to remove the adsorbed chemical substances to prevent desorption. The metal oxides (such as $\mathrm{TiO}_{2}, \mathrm{WO}_{3}, \mathrm{ZnO}, \mathrm{Fe}_{2} \mathrm{O}_{3}, \mathrm{Ta}_{2} \mathrm{O}_{5}$, and $\mathrm{CuO}$ ) are heterojunction photocatalysts [10]. Davari et al. reported that synthesized $\mathrm{ZnO} / \mathrm{Fe}_{2} \mathrm{O}_{3}$ and $\mathrm{TiO}_{2} / \mathrm{Fe}_{2} \mathrm{O}_{3}$ on zeolite could decompose the organic substance [11]. As the calcined green tuff contains small amounts of similar components, the elemental distribution is measured and investigated, especially for $\mathrm{TiO}_{2}$ existence on zeolite. If the natural photocatalyst exists, the synthetic photocatalyst production cost can be reduced. Photocatalytic production of hydrogen peroxide on semiconductors, such as $\mathrm{TiO}_{2}$, has been reported using water and oxygen with UV; however, hydrogen peroxide can be produced by using visible light [12,13]. The produced hydrogen peroxide can be decomposed by higher alkaline [14], UV light irradiation and Fenton reaction with $\mathrm{Fe}^{2+}$ ions. As the produced hydroxyl radical can react to formaldehyde, the better hydrogen peroxide decomposition conditions are examined after the calcination of green tuff at various temperatures. Hoshiba et al. reported the generation of hydroxyl radicals from the calcined dolomite powders dispersed in $\mathrm{H}_{2} \mathrm{O}_{2}$ [15]. In this experiment, the hydroxyl radical existence is measured with ESR and spin trapping agent G-CYPMPO under no UV and UV irradiation. The adsorption and decomposition of formaldehyde on photocatalyst rutile are also reported by Liu et al. [16]. Next, a certain amount of formaldehyde in a closed room can be adsorbed onto green tuff powder and tile and compared with activated carbon. In the practical use to remove formaldehyde associated with sick building syndrome [1], the tile is more convenient. The strength of produced tiles was also investigated by changing pressing and calcination conditions. In case of the adsorption of formaldehyde, the materials reached the saturation concentration of formaldehyde. It is suggested that the photocatalyst can decompose the adsorbed formaldehyde, due to the presence of the hydroxyl radical on calcined green tuff or tile.

\section{Materials and Methods}

\subsection{Materials of Green Tuff Powder}

The green tuff powder is a sedimentary rock that provides us with evidence about the formation process of the Japanese Archipelago [4] and is collected from the "Towada stone" cutting place in the quarry to produce architectural materials, such as walls and floor flat tiles in Odate city of Akita prefecture, Japan. The composition of the as-received green tuff is listed in Figure 1. As-received means original cutting waste green tuff powder less than -100 mesh in size. The composition was analyzed by means of an X-ray fluorescence spectroscope (XRF). The iron oxide is mainly ferrous in as-received powders. The main composition minerals are albite $35 \%$, quartz $25 \%$, chlorite $7 \%$, zeolite $5 \%$, stilbite $3 \%$ and laumontite $2 \%$ by XRD and the average density is $2.1 \mathrm{~g} / \mathrm{cm}^{3}$, the specific surface area is $4.0 \mathrm{~m}^{2} / \mathrm{g}$, the peak in pore size distribution is $51 \mathrm{~nm}$ and pore volume is $0.028 \mathrm{~cm}^{3} / \mathrm{g}$. [6]. The zero point of charge is about $\mathrm{pH} 2.5$ [7]. 


\begin{tabular}{|l|r|}
\hline \multicolumn{1}{|c|}{ Composition } & Content, $\mathrm{w} / \mathrm{v} \%$ \\
\hline $\mathrm{Na}_{2} \mathrm{O}$ & 0.30 \\
\hline $\mathrm{MgO}$ & 0.73 \\
\hline $\mathrm{Al}_{2} \mathrm{O}_{3}$ & 9.16 \\
\hline $\mathrm{SiO}_{2}$ & 61.69 \\
\hline $\mathrm{P}_{2} \mathrm{O}_{5}$ & 0.21 \\
\hline $\mathrm{SO}_{3}$ & 0.17 \\
\hline $\mathrm{Cl}$ & 0.04 \\
\hline $\mathrm{K}_{2} \mathrm{O}$ & 6.19 \\
\hline $\mathrm{CaO}$ & 4.07 \\
\hline $\mathrm{TiO}_{2}$ & 0.71 \\
\hline $\mathrm{MnO}$ & 0.49 \\
\hline $\mathrm{FeO}$ or $\mathrm{Fe}_{2} \mathrm{O}_{3}$ & $14.42 \sim 16.03$ \\
\hline $\mathrm{CO}_{2} \mathrm{O}_{3}$ & 0.01 \\
\hline $\mathrm{ZnO}$ & 0.07 \\
\hline $\mathrm{Rb}{ }_{2} \mathrm{O}$ & 0.03 \\
\hline $\mathrm{SrO}$ & 0.08 \\
\hline Total & $98.37 \sim 99.98$ \\
\hline
\end{tabular}

\title{
Minerals in Towada green tuff
}

\author{
Albite $\left(\mathrm{NaAlSi}_{3} \mathrm{O}_{8}\right)$ \\ Quartz $\left(\mathrm{SiO}_{2}\right) \quad 25 \%$ \\ Chlorite $(\mathrm{Mg}, \mathrm{Fe}, \mathrm{Al})_{6}(\mathrm{Si}, \mathrm{Al})_{4} \mathrm{O}_{10}(\mathrm{OH})_{8} \quad 7 \%$
}

Zeolite $5 \%$

Stilbite $\left(\mathrm{CaAl}_{2} \mathrm{Si}_{7} \mathrm{O}_{18} 7 \mathrm{H}_{2} \mathrm{O}\right) \quad(3 \%)$

Laumontite $\left(\mathrm{Ca}_{4} \mathrm{Al}_{8} \mathrm{Si}_{16} \mathrm{O}_{48} 18 \mathrm{H}_{2} \mathrm{O}\right) \quad(2 \%)$

Residual $\quad 28 \%$

Figure 1. Chemical composition of as-received green tuff (Towada stone) powder and mineral composition [6].

Next, the green tuff powder was calcined at $500{ }^{\circ} \mathrm{C}, 600{ }^{\circ} \mathrm{C}, 700{ }^{\circ} \mathrm{C}, 800{ }^{\circ} \mathrm{C}, 900{ }^{\circ} \mathrm{C}, 1000{ }^{\circ} \mathrm{C}$, $1100{ }^{\circ} \mathrm{C}$, and $1200^{\circ} \mathrm{C}$ for $10 \mathrm{~min}$, and the calcined powder was kept dry. As a result, all FeO changed to $\mathrm{Fe}_{2} \mathrm{O}_{3}$ by heating in an air atmosphere. The green tuff powder and the shape of the calcined powder were investigated by SEM, and the element distribution by EDS.

\subsection{Hydroxyl Radical Measurement by ESR}

The green tuff powder $(1 \mathrm{~g})$ was mixed in a $50 \mathrm{~mL}$ tube with $0.1 \mathrm{w} / v$ hydrogen peroxide, which was derived by diluting $35 w / v \%$ hydrogen peroxide. To investigate the radical characteristics, ESR measurement using a spin trap reagent is necessary. After mixing, the tube was strongly shaken for 10 seconds. In this study, a novel radical trapper, \{2-(5,5-dimethyl-2-oxo-1,3,2-dioxaphosphinan-2yl)-3,4-dihydro-2-methyl-2H-pyrrole N-oxide, G-CYPMPO\}, was used to trap free radicals [17]. The chemical structure of G-CYPMPO is shown in Figure 2a. G-CYPMPO®(100 mM, 25mg) was dissolved in $2 \mathrm{~mL}$ ultrapure water. $\mathrm{PO}_{4}$ buffer $1 \mathrm{mM}$ flow is used. A JEOL JES-TE25X ESR spectrometer was used to record ESR spectra of spin adducts. Typical ESR measurement conditions were as follows: microwave power, $4 \mathrm{~mW}$; microwave frequency, $9.2 \mathrm{GHz}$; magnetic field, $328.0 \mathrm{mT}$; field sweep with, $\pm 7.5 \mathrm{mT}$; field modulation, $0.16 \mathrm{mT}$; sweep time, $1 \mathrm{~min} ; 0.003663 \mathrm{mT} /$ Point, 4096 points in total. ESR measurements were performed at room temperature.

The hydroxyl radical is generated by the decomposition of $0.1 \mathrm{w} / \mathrm{t} \%$ hydrogen peroxide under $5 \mathrm{~s}$ UV-irradiation with a UV-irradiator (SUPERCURE-203S UV LIGHTSOURCE, USHIO INC., Tokyo, Japan) and the observed ESR spectra are shown in Figure $2 b$.

ESR of G-CYPMPO toward the hydroxyl radical has been investigated by Oka et al. and shows eight peaks [18]. It is possible to compare any peaks of hydroxyl radicals; however, in this experiment, the central 4th peak (marked with inverted triangle) is used to compare ESR intensity for hydroxyl radicals in the absence and presence of green tuff powders. Also, Kohri et al. used the one central peak to compare the other data [19]. In the plot of $\mathrm{I}_{0} / \mathrm{I}-1, \mathrm{I}_{0}$ and I denote ESR intensity in the absence and presence of green tuff powder oxidant species, respectively. To investigate the effect on calcination temperature of green tuff powder for free radical generation, $0.5 \mathrm{~g}$ of green tuff powder, calcined at different temperature, was hydrated with $0.1 w / v$ hydrogen peroxide for $24 \mathrm{~h}$ before ESR measurement. 
<smiles>CC1(C)COP(=O)(C2(C)CCC=[N+]2[O-])OC1</smiles>

(a)

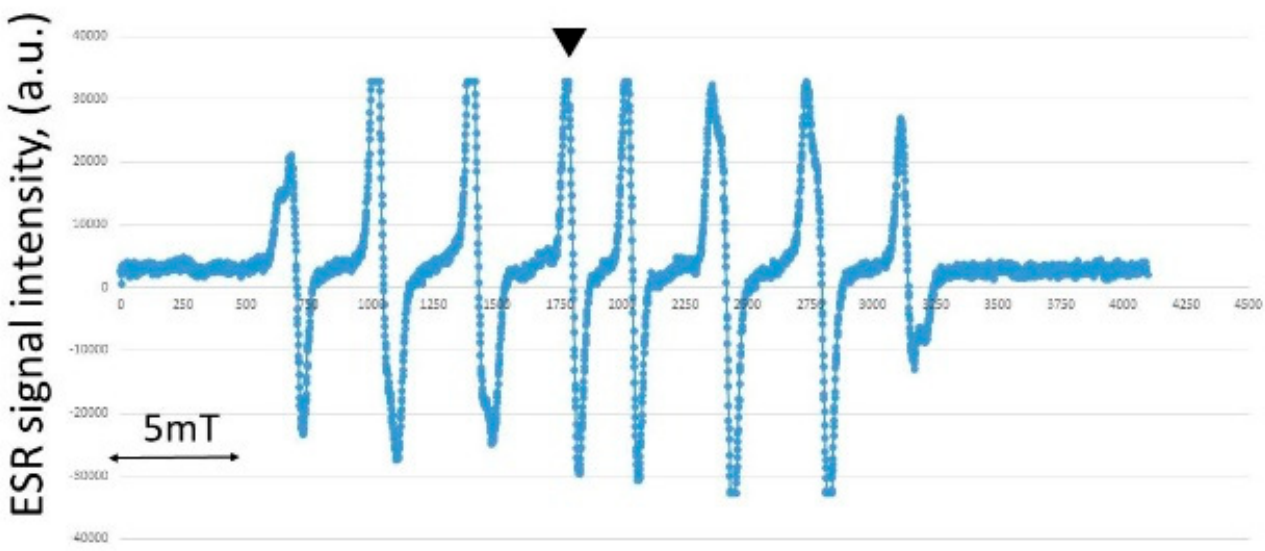

(b)

Figure 2. Chemical Structure of G-CYPMPO (a) and the ESR spectra of G-CYPMPO-trapped adduct in UV-illuminated hydrogen peroxide solution $(0.1 w / v \%)(\mathbf{b})$.

\subsection{Production of Tile Using Calcined Green Tuff Powders}

The calcined powders are used to produce the tile. The tile can be used as building materials (i.e. for wall and floor), since its quality is comparable to other conventional materials. In this experiment the small manually operated molding machine is used to produce the rectangular molded blocks as shown in Figure 3.

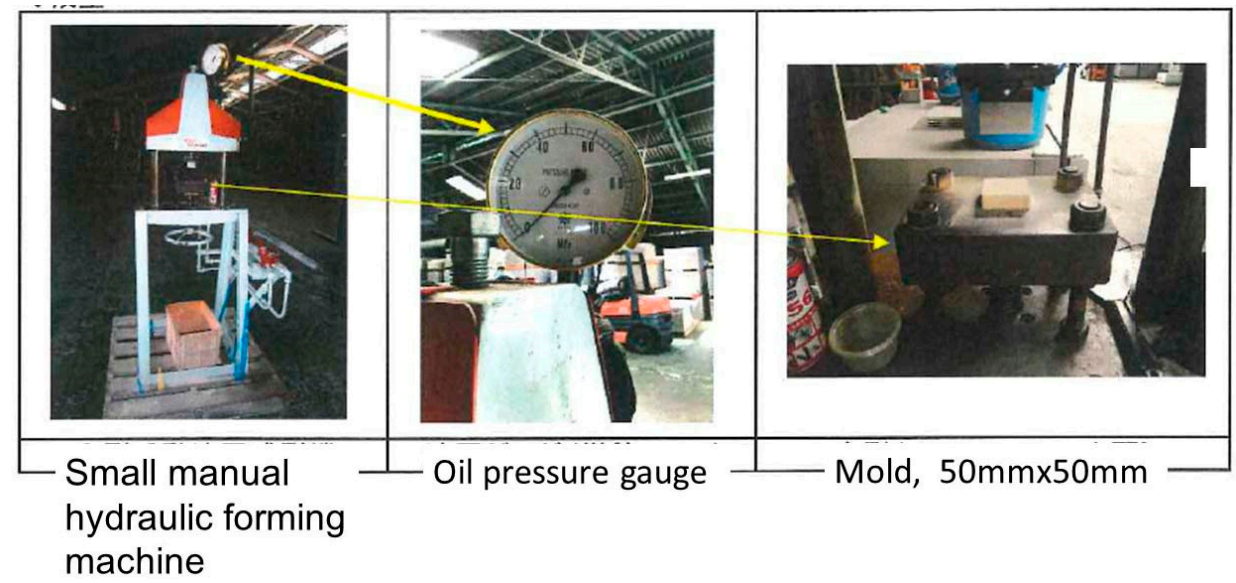

Figure 3. Photographs of oil pressure molding apparatus.

A $55 \mathrm{~g}$ sample of green tuff powders was first calcined at $800{ }^{\circ} \mathrm{C}$ and then used for molding in each block without additives. Two pressures, 20 and $40 \mathrm{MPa}$, are applied to form the blocks with no additives. Next, the molded blocks are heated and kept at 800,1000 and $1100^{\circ} \mathrm{C}$ for $15 \mathrm{~min}$. The blocks are heated at those temperatures and pressures by using $800^{\circ} \mathrm{C}$ calcined green tuff powder and several tiles are produced. The photograph of produced tiles is shown in Figure 4. The color of tile changed 
from yellow to black at $1100{ }^{\circ} \mathrm{C}$. The strength of tile produced at $110{ }^{\circ} \mathrm{C}$ and $40 \mathrm{MPa}$ is the highest. On the other hand, the tile heated at $800{ }^{\circ} \mathrm{C}$ is easily broken and forms a powder. Therefore, only tiles heated at $1000{ }^{\circ} \mathrm{C}$ and $1100{ }^{\circ} \mathrm{C}$ are used in this experiment.

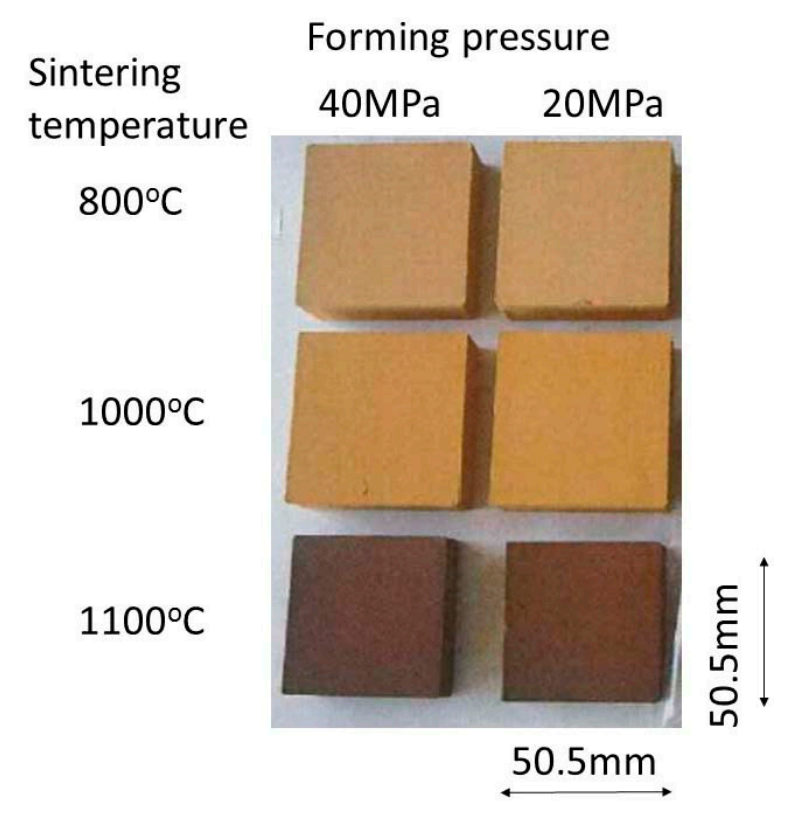

Figure 4. Photograph of tiles prepared by using compressed $800{ }^{\circ} \mathrm{C}$ green tuff powder. (Tile size is 50.5 $\times 50.5 \mathrm{~mm}$, Thickness $14.5 \mathrm{~mm}$ at $40 \mathrm{MPa}$ and $15.7 \mathrm{~mm}$ at $20 \mathrm{MPa}$ ).

\subsection{Formaldehyde Adsorption Experimental Method}

Formaldehyde at concentrations above $0.1 \mathrm{ppm}$ in air can irritate the eyes and mucous membranes, resulting in watery eyes, causing the so-called sick building syndrome. The adsorption experiment of formaldehyde is studied using various green tuff powders and tile. The reagent grade formaldehyde ( $\mathrm{HCOH}$, Wako Pure Chemical Industries, Ltd, Osaka, Japan) is about 37\% aqueous solution with methanol. A small amount of formaldehyde is vaporized in the $0.25 \mathrm{~m}^{3}$ of glove box. The initial concentration of formaldehyde in glove box is regulated at $0.6 \mathrm{ppm}$. Next, $55 \mathrm{~g}$ of green tuff powder or tile is put on the floor in the glove box and the concentration of formaldehyde is measured as a function of time. The weight percent of green tuff in the room is $220 \mathrm{~g} / \mathrm{m}^{3}$. The comparison of adsorption, the granular activated carbon (Wako Pure Chemical Industries, Ltd, Osaka, Japan) is used at the same weight. Formaldehyde concentration is measured by a formaldehyde detector (FP31, RIKEN KEIKI Co., Ltd, Tokyo, Japan).

\section{Results and Discussion}

\subsection{Calcined Green Tuff Powder}

The surface structure has been observed by SEM, and $\mathrm{Al}, \mathrm{Mg}, \mathrm{Si}, \mathrm{Fe}, \mathrm{Ca}, \mathrm{Zn}$ and Ti elemental maps are obtained. Figure 5 shows the SEM imagines of the fine particles, calcinated at $800{ }^{\circ} \mathrm{C}$ and compared with as-received particles. At $1100{ }^{\circ} \mathrm{C}$, the small particles are coagulated and sintered to slightly larger particles, compared with particles calcinated at $800^{\circ} \mathrm{C}$; however, several pores are still observed. The elemental maps show that $\mathrm{Si}$ and $\mathrm{Al}$, the main elements, have similar distributions except for quartz, considering the mineral composition shown in Figure 2. The corresponding particles of $\mathrm{Mg}$ and Fe map show mainly chlorite. The Ca map shows mainly zeolite in Figure 2. A concentrated Ti map corresponds to the Ca map and they are indicated in circles, which are observed in all as-received samples and those calcined at $800{ }^{\circ} \mathrm{C}$ and $1100{ }^{\circ} \mathrm{C}$. On the other hand, the $\mathrm{Zn}$ map cannot be measured due to a small percentage. The fine grains of $\mathrm{TiO}_{2}$ on zeolite may be a photocatalyst in any green tuff. 
As-received green tuff powder
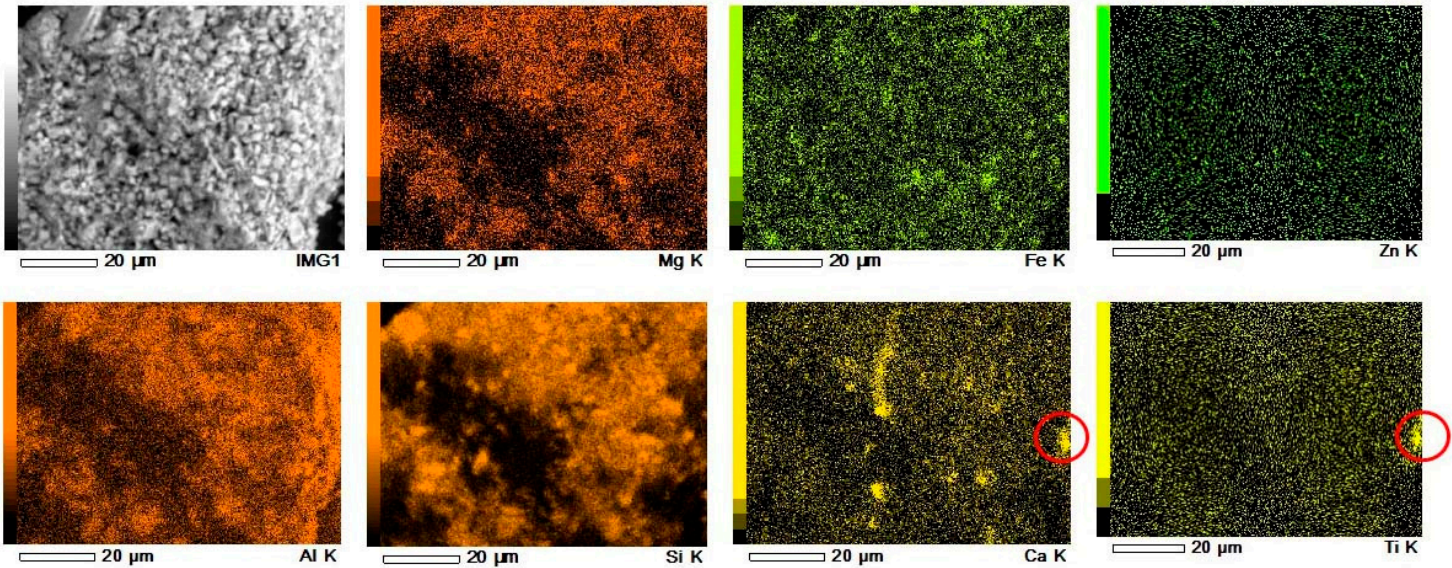

(a)

$800^{\circ} \mathrm{C}$ calcined green tuff powder
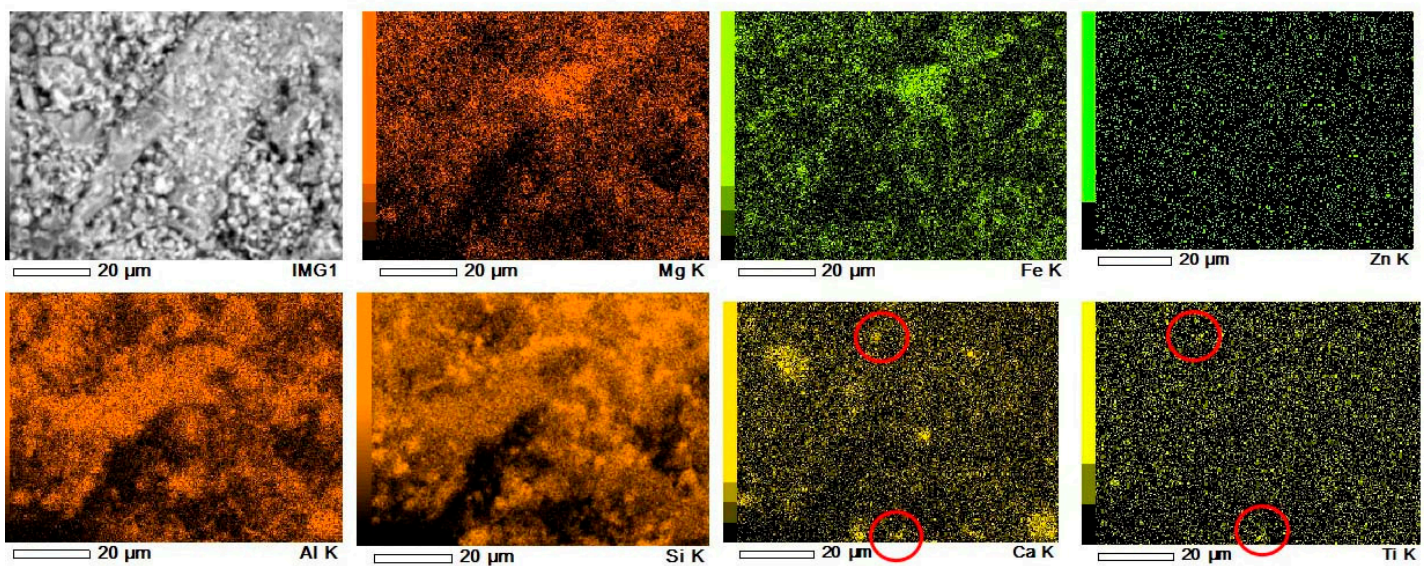

(b)

$1100^{\circ} \mathrm{C}$ calcined green tuff powder
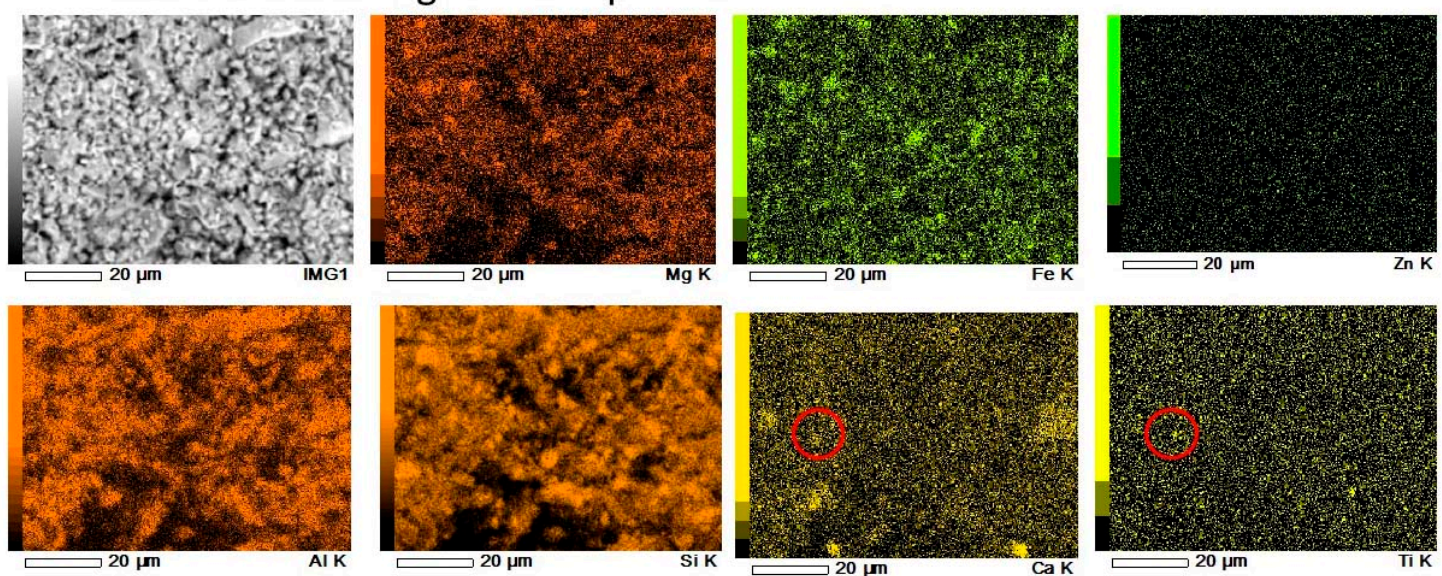

(c)

Figure 5. SEM and EDS elemental maps of $\mathrm{Mg}, \mathrm{Fe}, \mathrm{Al}, \mathrm{Si}, \mathrm{Ca}, \mathrm{Ti}$ and $\mathrm{Zn}$ for as-received (a), $800{ }^{\circ} \mathrm{C}$ calcined (b) and $1100{ }^{\circ} \mathrm{C}$ calcined (c) green tuff powder. Ti and Ca corresponding locations are shown in red circles. 
If $\mathrm{TiO}_{2}$ on zeolite in green tuff and calcined green tuff are photocatalyst, the hydrogen peroxide can be produced as indicated in the following equation as positive hole $\mathrm{h}^{+}[12,19]$.

$$
\begin{gathered}
\mathrm{H}_{2} \mathrm{O}+2 \mathrm{~h}^{+} \rightarrow 1 / 2 \mathrm{O}_{2}+2 \mathrm{H}^{+}, \\
\mathrm{O}_{2}+2 \mathrm{H}^{+}+2 \mathrm{e}^{-} \rightarrow \mathrm{H}_{2} \mathrm{O}_{2},
\end{gathered}
$$

\section{2. pH Change of Calcined Green Tuff Powder}

The produced hydrogen peroxide is unstable at higher $\mathrm{pH}$ [14] and is decomposed to hydroxyl radicals. The effect of $\mathrm{pH}$ in dispersed calcined green tuff and as-received green fuff have been investigated. The $1 \mathrm{wt} \%$ of as-received green tuff powder and green tuff powder calcined at $500{ }^{\circ} \mathrm{C}$, $800{ }^{\circ} \mathrm{C}, 1200^{\circ} \mathrm{C}$ are put into ion-exchange water and agitated by a magnetic stirrer. The $\mathrm{pH}$ of the passed agitation time is shown in Figure 6. The green tuff powder calcined at $500^{\circ} \mathrm{C}$ and $800{ }^{\circ} \mathrm{C}$ shows higher $\mathrm{pH}$ compared with as-received green tuff at 9.7 , whereas the $1200^{\circ} \mathrm{C}$ calcined tuff powder has a lower $\mathrm{pH}$. The highest $\mathrm{pH}$ shows $800^{\circ} \mathrm{C}$ calcined green tuff and reaches $\mathrm{pH} 10.7$. This $\mathrm{pH}$ increase by calcination is similar to the calcined dolomite [15]. The alkaline solution can decompose hydrogen peroxide and it seems the $800{ }^{\circ} \mathrm{C}$ calcined green tuff has the greatest decomposition ability.

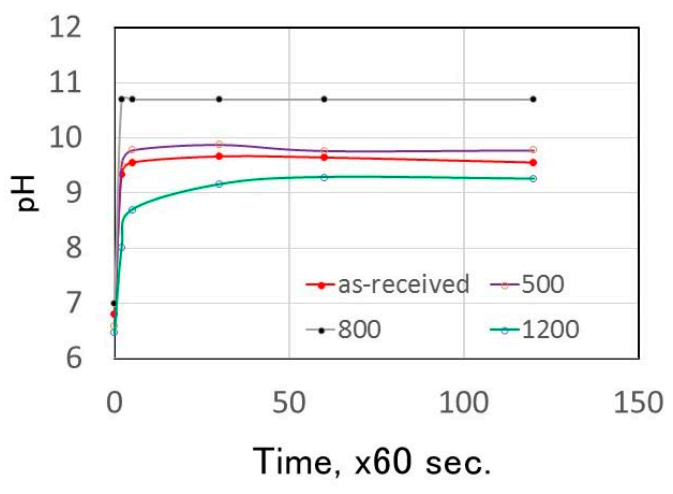

Figure 6. $\mathrm{pH}$ change depending on time for as-received green tuff and calcined green tuff at different temperatures.

\subsection{Results of Hydroxyl Radical Measurement}

The green tuff powder and calcined powder are put into $0.1 \mathrm{wt} \% \mathrm{H}_{2} \mathrm{O}_{2}$ solution. ESR spectrum measured after $24 \mathrm{~h}$ without UV irradiation is shown in Figure 7. There is no spectrum for powder added to only $0.1 \mathrm{wt} \% \mathrm{H}_{2} \mathrm{O}_{2}$ solution and green tuff powder calcined at $1200^{\circ} \mathrm{C}$. In the as-received green tuff powder, small peaks of ESR spectrum are observed. On the other hand, green tuff powder calcined at $800^{\circ} \mathrm{C}$ shows a large ESR spectrum of hydroxyl radical even if it is not UV irradiated. It is considered that the $\mathrm{H}_{2} \mathrm{O}_{2}$ decomposed by powder calcined at $800{ }^{\circ} \mathrm{C}$ with higher $\mathrm{pH}$ as shown in Figure 6 . When strong UV light is applied to the all specimens, large hydroxyl radical ESR peaks are observed. The ESR spectra of only $0.1 \%$ of $\mathrm{H}_{2} \mathrm{O}_{2}$ in water and green tuff calcined at $800{ }^{\circ} \mathrm{C}$ added to $0.1 \%$ of $\mathrm{H}_{2} \mathrm{O}_{2}$ in water with UV are shown in Figure 8. The height of the fourth peak is compared. The hydroxyl radical can decrease by the addition of calcined green tuff. The ESR peak ratio $I_{0} / I-1$ depending on calcined temperature and $\mathrm{pH}$ is shown in Figure 9. The green tuff calcined at $800{ }^{\circ} \mathrm{C}$ decreases the hydroxyl radical at the highest $\mathrm{pH}$. When the calcination temperature is higher than $120{ }^{\circ} \mathrm{C}$ it is impossible to decompose the hydroxyl radical by decreasing the $\mathrm{pH}$. At higher than $\mathrm{pH} 10$, the decomposition of hydrogen peroxide occurs easily. By irradiating UV light, $\mathrm{H}_{2} \mathrm{O}_{2}$ produces the hydroxyl radical $(\cdot \mathrm{OH})$ in the following equation [20]. Here, $\mathrm{h}$ is Plank's constant and $v$ is light frequency.

$$
\mathrm{H}_{2} \mathrm{O}_{2}+\mathrm{h} v=2 \cdot \mathrm{OH},
$$


The Fenton reaction is shown by the following equation; however, this spectrum by ESR is indicated by Equation (3), as the iron in calcined green tuff is $\mathrm{Fe}^{3+}$.

$$
\mathrm{Fe}^{2+}+\mathrm{H}_{2} \mathrm{O}_{2} \rightarrow \mathrm{Fe}^{3+}+\mathrm{OH}-+\cdot \mathrm{OH},
$$

The green tuff calcined from $600{ }^{\circ} \mathrm{C}$ to $1100{ }^{\circ} \mathrm{C}$ reduces the hydroxyl radical faster and the one calcined at $800^{\circ} \mathrm{C}$ is the largest reduction material of the hydroxyl radical.

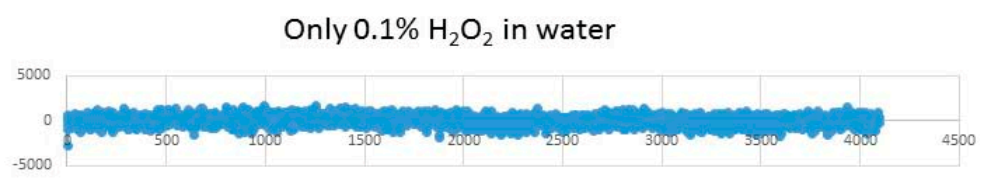

\section{As-received green tuff}

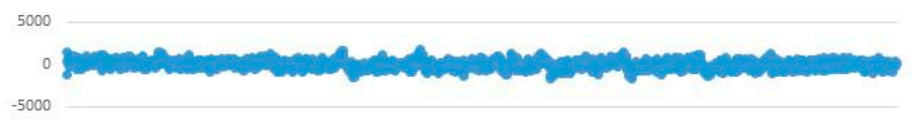

Green tuff calcined $800^{\circ} \mathrm{C}$

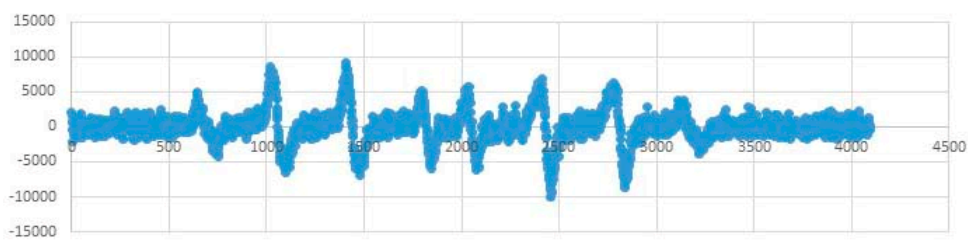

Green tuff calcined at $1200^{\circ} \mathrm{C}$

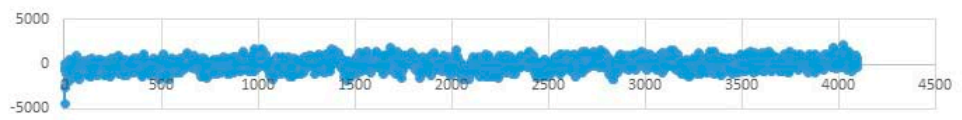

No UV light

Figure 7. ESR spectra of $0.1 \%$ of $\mathrm{H}_{2} \mathrm{O}_{2}$ in water, as-received green tuff, calcined $800{ }^{\circ} \mathrm{C}$ green tuff and $1200{ }^{\circ} \mathrm{C}$ calcined green tuff added to $0.1 \%$ of $\mathrm{H}_{2} \mathrm{O}_{2}$ in water without UV.

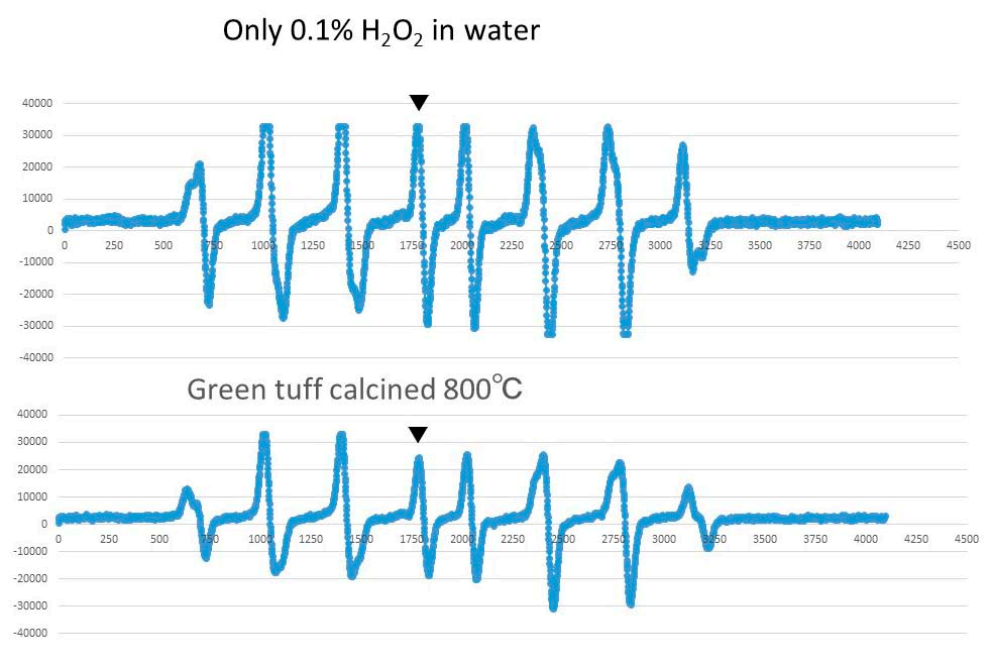

\section{Applied UV light}

Figure 8. ESR spectra of $0.1 \%$ of $\mathrm{H}_{2} \mathrm{O}_{2}$ in water and calcined $800{ }^{\circ} \mathrm{C}$ green tuff added to $0.1 \%$ of $\mathrm{H}_{2} \mathrm{O}_{2}$ in water with UV. 


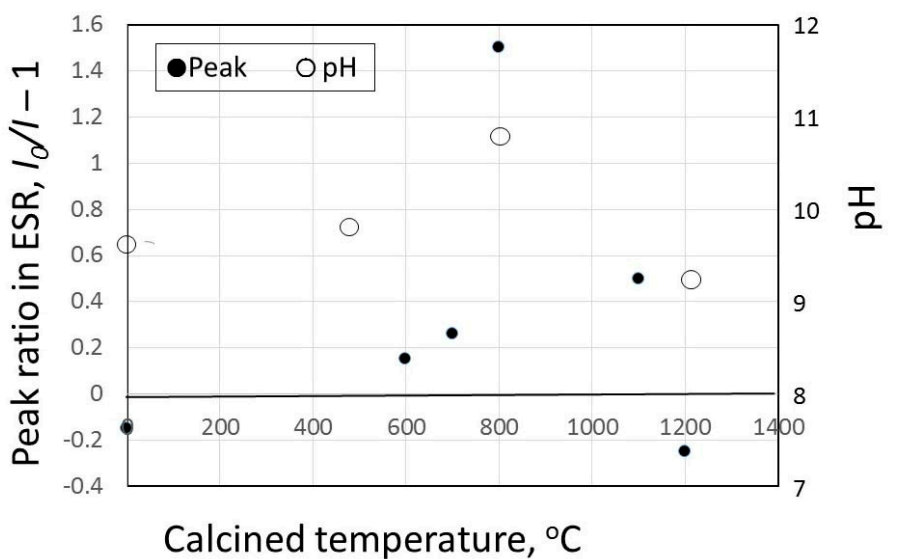

Figure 9. ESR peak ratio depending on calcined temperature.

\subsection{Formaldehyde Adsorption Result}

The fitting curves and measured point of formaldehyde concentration depending on time for two kinds of tiles produced by using $800{ }^{\circ} \mathrm{C}$ calcined green tuff powder, its powder and as-received powder are shown in Figure 10. To compare the adsorption ability, the activated carbon is also measured. The green tuff powder calcined at $800{ }^{\circ} \mathrm{C}$ shows the largest formaldehyde adsorption and near to the line using activated carbon powder. The tile heated at $1000^{\circ} \mathrm{C}$ and $1100{ }^{\circ} \mathrm{C}$ shows almost the same adsorption behaviour. As the specific surface area of powder is larger than the same weight of tile, the adsorption ability of powder is much higher. However, the tile is more convenient to be used as building material. The $800{ }^{\circ} \mathrm{C}$ calcined powder is the most convenient to change hydrogen peroxide to the hydroxyl radical with no UV as shown in Figure 7, whereas the decomposed hydroxyl radical with UV is shown in Figure 9. However, it is difficult to produce the tile at $800{ }^{\circ} \mathrm{C}$. Therefore, the tile produced at higher temperature has been heated for $15 \mathrm{~min}$ at $1000{ }^{\circ} \mathrm{C}$ and $1100{ }^{\circ} \mathrm{C}$. The period to decrease to $50 \%$ of formaldehyde concentration using different adsorbent is shown in Figure 11. The half value of period in green tuff powder calcined at $800{ }^{\circ} \mathrm{C}$ is $5 \mathrm{~h}$, while the tiles heated at 1000 and $1100{ }^{\circ} \mathrm{C}$ are $10 \mathrm{~h}$. The structure of calcined powder and tile is porous, containing zeolite; therefore, the adsorption rate is high. The calcined green tuff contains $0.71 \%$ of $\mathrm{TiO}_{2}$ and $0.07 \%$ of $\mathrm{ZnO}$ and $16 \%$ of $\mathrm{Fe}_{2} \mathrm{O}_{3}$. The synthesized $\mathrm{ZnO} / \mathrm{Fe}_{2} \mathrm{O}_{3}$ and $\mathrm{TiO}_{2} / \mathrm{Fe}_{2} \mathrm{O}_{3}$ on zeolite produced by Davari et al. could decompose the organic substance as photocatalyst [11]. Though the mechanism for former reported tile and materials $[8,9]$ to reduce the formaldehyde is only adsorption, the tile produced by calcined green tuff has the potential to decompose the adsorbed formaldehyde as per the following equation by the photocatalyst.

$$
\mathrm{HCHO}+\mathrm{O}_{2} \rightarrow \mathrm{CO}_{2}+\mathrm{H}_{2} \mathrm{O},
$$

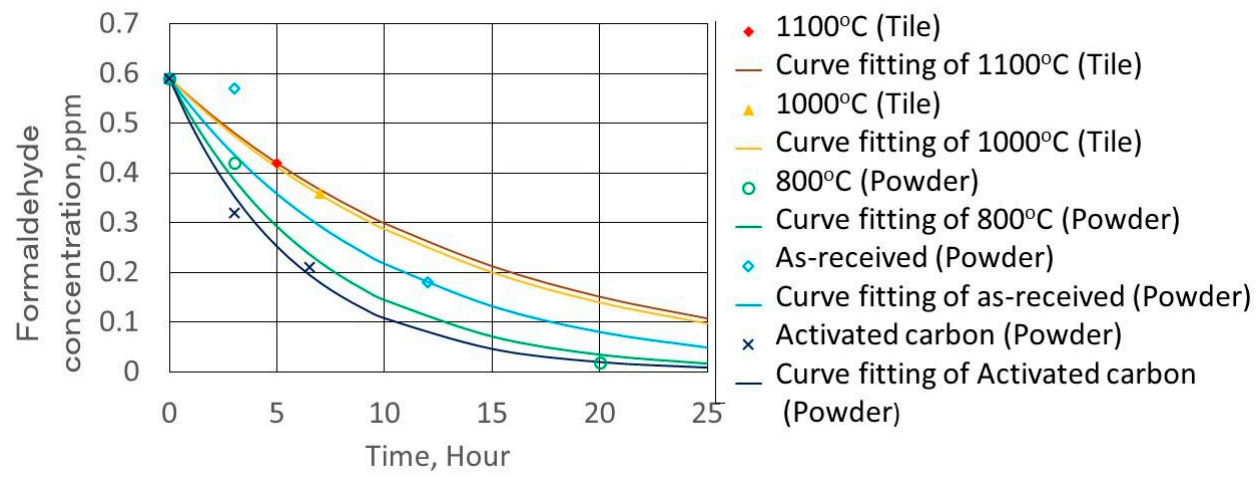

Figure 10. Formaldehyde concentration change depending on time for two tiles produced by using $800{ }^{\circ} \mathrm{C}$ calcined green tuff powder and $800{ }^{\circ} \mathrm{C}$ calcined green tuff powder and activated carbon. 


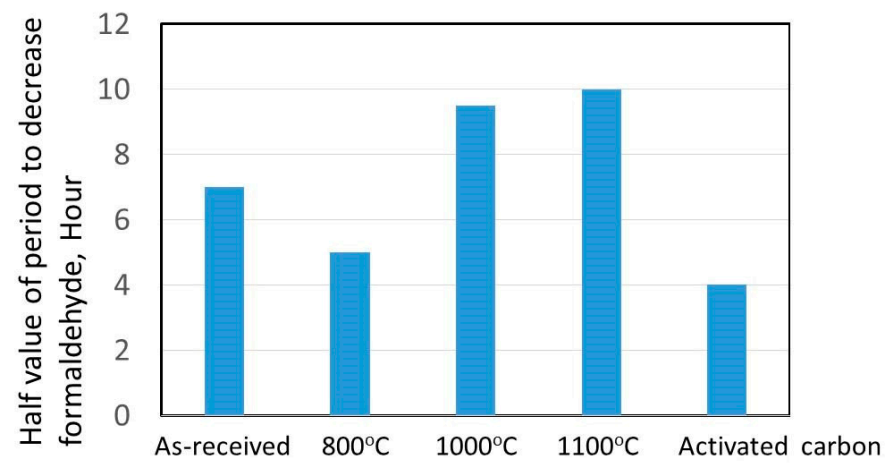

Figure 11. Half value of period to decrease formaldehyde concentration in each adsorbent.

\section{Conclusions}

In an attempt to contribute to sustainable development, waste green tuff powder produced by cutting Towada stone was utilized to eliminate formaldehyde, one of the many greenhouse gases, and the following results were obtained.

As the SEM and elemental map with EDS showed that fine $\mathrm{TiO}_{2}$ exists on zeolite in green tuff powder, the green tuff powder and calcined powder were found to be natural photocatalysts.

The green tuff powder calcined at $800{ }^{\circ} \mathrm{C}$ showed the highest alkaline solution of $\mathrm{pH} 10.8$ in water. At $\mathrm{pH}$ higher than 10, the decomposition of hydrogen peroxide to hydroxyl radicals without UV light occurs easily.

Under UV irradiation, the green tuff powder calcined at $800{ }^{\circ} \mathrm{C}$ most strongly decreased the amount of hydroxyl radicals in hydrogen peroxide aqueous solution. The as-received green tuff and that calcined at more than $1200{ }^{\circ} \mathrm{C}$ did not decrease the hydroxyl radical.

The tile was produced by pressing the $800^{\circ} \mathrm{C}$ calcined green tuff powder with no additives. At $40 \mathrm{MPa}$ and heating at $1100^{\circ} \mathrm{C}$ for $15 \mathrm{~min}$, the tile showed the largest strength, when compared with tiles produced by heating at 800 and $1000^{\circ} \mathrm{C}$.

Regarding the formaldehyde adsorption, the green tuff powder calcined at $800{ }^{\circ} \mathrm{C}$ showed that after $5 \mathrm{~h}$, the formaldehyde concentration decreased to half of its initial concentration and a high adsorption rate similar to the activated carbon was observed. The tile heated at $1100{ }^{\circ} \mathrm{C}$ also adsorbed formaldehyde.

The adsorbed formaldehyde might be decomposed by hydroxyl radical produced for the presence of $\mathrm{TiO}_{2}$ on zeolite in green tuff and tile as photocatalyst.

Author Contributions: Conceptualization, T.F, L.Z; investigation, L.Z., H.K. (Hiromi Kurokawa), H.M., S.Y., H.K. (Hiroshi Kawaguchi); writing-original draft preparation, T.F., L.Z.; writing-review and editing, G.D.; supervision, Y.W., G.D., J.A.

Funding: This research received no external funding.

Acknowledgments: We appreciate the measurement of formaldehyde by K. Okaya, the tile production by the Glass Recycling Committee of Japan and SEM assistance by Otsuka and Fukawa. Also, G-CYPMPO was supplied by M. Kamibayashi. A part of this work was conducted at the Advanced Characterization Nanotechnology Platform of the University of Tokyo, supported by the "Nanotechnology Platform" of the Ministry of Education, Culture, Sports, Science and Technology (MEXT), Japan.

Conflicts of Interest: The authors declare no conflict of interest.

\section{References}

1. EPA. 42 U.S. Code $\$ 7412$. Hazardous Air Pollutants. 1992. Available online: https://www.law.cornell.edu/ uscode/text/42/7412 (accessed on 19 June 2019).

2. Measuring Global Water Vapor and Formaldehyde. Science News. 14 April 2010. Available online: https://www.sciencedaily.com/releases/2010/04/100409134731.htm (accessed on 19 June 2019). 
3. Green Tuff. 2013. Available online: http://www.oki-geopark.jp/en/episode/geohistory/stage2/green-tuff/ (accessed on 19 June 2019).

4. Towada Green-Tuff AgroScience Co., Ltd. 2018. Available online: https://towadagreentuff.com/company.html (accessed on 19 June 2019).

5. Mitsumori, H.; Aiba, N.; Saito, M.; Nagasawa, Y. A Study on the Use of Towada Stones in Food Processing. Bull. Seirei Women's J. Coll. 2011, 39, 14-25. [CrossRef]

6. Sugai, Y.; Sasaki, K.; Matsubaya, O.; Naka, H.; Tanaka, F. The abilities of Hinai-Green Tuff to adjust pH and activate of microorganisms. Shigen-To-Sozai 2005, 121, 513-520. [CrossRef]

7. Nakamura, T.; Okawa, H.; Kawamura, Y.; Takahata, S.; Naka, H.; Sugawara, K. Research on the New Method to Precipitate Hinai Green Tuff Suspension using Ultrasound Irradiation. Resour. Process. 2009, 56, 13-20. [CrossRef]

8. Sugai, Y.; Sasaki, K.; Takahata, S.; Naka, H. Characteristics of functional wall material containing a green tuff. Soc. Heat. Air-Cond. Sanit. Eng. Jpn. 2007, 32, 1-10. [CrossRef]

9. LIXIL (INAX), ECOCARAT. 2019. Available online: https://ecocarat.jp/features/,https://ecocarat.jp/features/3. html (accessed on 19 June 2019).

10. Grabowska, E.; Marchelek, E.M.; Paszkiewicz-Gawron, M.; Zaleska-Medynska, A. 3-Metal Oxide Photocatalysts, Metal Oxide-Based Photocatalysis; Elsevier Inc.: Amsterdam, The Netherlands, 2018; ISBN 9780128116340.

11. Davari, N.; Farhadian, M.; Nazar, A.R.S.; Homayoonfal, M. Degradation of diphenhydramine by the photocatalysis of $\mathrm{ZnO} / \mathrm{Fe}_{2} \mathrm{O}$ and $\mathrm{TiO}_{2} / \mathrm{Fe}_{2} \mathrm{O}_{3}$ based on clinoptilolite: Structural and operational comparison. J. Environ. Chem. Eng. 2017, 5, 5707-5720. [CrossRef]

12. Ma, R.Y.; Wang, L.; Wang, H.; Liu, Z.Y.; Xing, M.Y.; Zhu, L.F.; Meng, X.J.; Xiao, F.S. Solid acids accelerate the photocatalytic hydrogen peroxide synthesis over a hybrid catalyst of Titania nanotube with carbon dot. Appl. Catal. B Environ. 2019, 244, 594-603. [CrossRef]

13. Baran, T.; Wojtyła, S.; Minguzzi, A.; Rondinini, S.; Vertova, A. Achieving efficient $\mathrm{H}_{2} \mathrm{O}_{2}$ production by a visible-light absorbing, highly stable photosensitized $\mathrm{TiO}_{2}$. Appl. Catal. B Environ. 2019, 244, 303-312. [CrossRef]

14. Duke, F.R.; Haas, T.W. The Homogeneous Base-Catalyzed Decomposition of Hydrogen Peroxide. J. Phys. Chem. 1961, 65, 304-306. [CrossRef]

15. Hoshiba, K.; Ponou, J.; Dodbiba, G.; Ito, H.; Sase, T.; Matsui, H.; Fujita, T. Effect of Calcination Temperature on the Hydroxyl Radical Generation of Calcined Dolomite Suspension. J. MMIJ 2018, 134, 151-157. [CrossRef]

16. Liu, L.M.; Zhao, J. Formaldehyde adsorption and decomposition on rutile (110): A first-principles study. Surf. Sci. 2016, 652, 156-162. [CrossRef]

17. Oka, T.; Midoricawa, M.; Saiki, S.; Muroya, Y.; Kamibayasshi, M.; Yamashita, M.; Anzai, K. Spin-Trapping Reactions of a Novel Gauchetype Radical Trapper G-CYPMPO. Anal. Chem. 2011, 83, 9600-9604. [CrossRef] [PubMed]

18. Kohri, S.; Fujii, H.; Oowada, S.; Endoh, N.; Sueishi, Y.; Kusakabe, M.; Shimmei, M.; Kotake, Y. An oxygen radical absorbance capacity-like assay that directly quantifies the antioxidant's scavenging capacity against AAPH-derived free radicals. Anal. Biochem. 2009, 386, 167-171. [CrossRef] [PubMed]

19. Sakthivel, T.; Venugopal, G.; Durairaj, A.; Vasanthkumar, S.; Huang, X. Utilization of the internal electric field in semiconductor photocatalysis: A short review. J. Ind. Eng. Chem. 2019, 72, 18-30. [CrossRef]

20. Wang, F.; Smith, D.W.; El-Din, M.G. Application of advanced oxidation methods for landfill leachate treatment-A review. J. Environ. Eng. Sci. 2003, 2, 413-427. [CrossRef]

(C) 2019 by the authors. Licensee MDPI, Basel, Switzerland. This article is an open access article distributed under the terms and conditions of the Creative Commons Attribution (CC BY) license (http://creativecommons.org/licenses/by/4.0/). 